\title{
Potensi Stenochlaena palustris Burm. Sebagai Agen Antiinflamasi Berdasarkan Metode Ekstraksi PEF (Pulsed Electric Field): Sebuah Kajian Naratif
}

\author{
Nazrun ${ }^{1}$, Nur Hidayatiandri ${ }^{1}$, Susanti ${ }^{2}$, Robby Gus Mahardika ${ }^{1,}$ \\ ${ }^{1}$ Jurusan Kimia, Fakultas Teknik, Universitas Bangka Belitung \\ ${ }^{2} J u r u s a n$ Fisika, Fakultas Teknik, Universitas Bangka Belitung \\ *email korespondensi: robbygusmahardika@gmail.com
}

Received : 4 Desember 2020; Revised : 1 Maret 2021; Accepted : 19 September 2021; Published : 22 Desember 2021

\section{ABSTRAK}

Penyakit tidak menular (Non Communicable Disease (NCD) masih mendominasi penyebab kematian secara global. Ada beberapa faktor yang menyebabkan masyarakat terjangkit NCD, salah satunya adalah lemahnya daya tahan tubuh akibat pola hidup masyarakat yang kurang sehat. Salah satu cara untuk meningkatkan daya tahan tubuh dari berbagai penyakit adalah adanya agen antiinflamasi khususnya dari bahan alam. Salah satunya adalah pucuk merah iding-iding (Stenochlaena palustris Burm.). Tanaman ini merupakan tanaman yang banyak tumbuh di Bangka Belitung yang dipercaya sebagai obat tradisional untuk pengobatan penyakit nyeri, bisul, penyakit kulit, dan penguat darah. Pemilihan metode ekstraksi yang tepat menjadi kunci kefektifan ekstraksi zat aktif dari bahan alam. Salah satu metode yang yang efektif adalah PEF (Pulsed Electric Field) yang memadukan metode non termal dengan penerapan medan listrik tegangan tinggi dalam waktu yang singkat. Di dalam artikel ini dilakukan kajian naratif terkai potensi antiinflamasi ekstrak pucuk merah iding iding (S. palustris Burm.) menggunakan metode ekstraksi PEF (Pulsed Electric Field). Berbagai kajian kandungan senyawa pucuk iding-iding dikomparasikan dengan senyawa-senyawa atau ekstrak aktif sebagai antiinflamasi. Selanjutnya, dalam artikel ini juga dipaparkan potensi penggunaan metode ekstraksi senyawa aktif menggunakan PEF. Hal ini dikarenakan metode PEF ini memiliki prospek yang menjanjikan mengingat waktu ekstraksi yang lebih singkat dan tidak memerlukan panas sehingga senyawa-senyawa aktif tidak mengalami degradasi. Selain itu dipaparkan juga prospek dari penggunaan PEF sebagai metode ekstraksi dalam industri herbal sehingga menjadi masukan untuk penelitian ke depan.

Kata-kata kunci: antiinflamasi; Pulsed Electric Field; Stenochlaena palustris Brum

\section{PENDAHULUAN}

Penyakit tidak menular (Non Communicable Disease (NCD) masih mendominasi penyebab kematian secara global. Penyakit tidak menular (NCD) membunuh 41 juta orang setiap tahun, setara dengan $71 \%$ dari semua kematian secara global. Setiap tahun, 15 juta orang meninggal karena NCD antara usia $30-69$ tahun. Lebih dari $85 \%$ dari kematian akibat NCD ini terjadi di negara berpenghasilan rendah dan menengah. Penyakit kardiovaskular menyebabkan sebagian besar kematian NCD atau 17,9 juta orang setiap tahun, diikuti oleh kanker (9,0 juta), penyakit pernapasan (3,9 juta), dan diabetes (1,6 juta) (WHO, 2018).

Salah satu penyebab NCD ini adalah terjadinya oksidatif dalam tubuh akibat radikal bebas yang menyebabkan kerusakan dan inflamasi (peradangan) sel yang mengarah pada resiko tekena penyakit degeneratif seperti kanker, gagal jantung, kardiovaskuler (Hasim et al., 2019). Salah satu upaya untuk meningkatkan daya tahan dari berbagai penyakit adalah konsumsi agen antiinflamasi alami seperti pucuk merah iding-iding (Stenochlaena palustris Burm.). Tanaman ini merupakan tanaman yang banyak tumbuh di Bangka Belitung yang dipercaya sebagai obat tradisional untuk pengobatan penyakit nyeri, bisul, penyakit kulit, dan penguat darah (Roanisca, 2018).

S. palustris Burm. merupakan salah satu jenis tumbuhan paku-pakuan, yang banyak juga dikenal dengan nama lemidi, lemiding, ramiding, pau raurau, paku hurang, dan kelakai. Tumbuhan ini dapat tumbuh menjalar panjang hingga mencapai 5-10 m dengan akar rimpang yang kuat dan pipih. Pada daun iding-iding terdapat 8-15 pasang anak daun. Berdasarkan penelitian sebelumnya, pucuk merah iding-iding banyak mengandung flavonoid, polifenol, asam hidroksi sinamat dan antrosianin (Chai, 2012). Hasil penelitian yang dilakukan oleh Pardede et al. (2018) menemukan bahwa ekstrak daun S. palustris Burm mengandung senyawa golongan flavonoid, steroid yang telah banyak dilaporan memiliki aktivitas sebagai antiinflamasi (Pardede et al., 2018). Total flavonoid yang terkandung di dalam ekstrak daun adalah 14,5 
$\mu \mathrm{g} / \mathrm{ml}$. Zat bioaktif lain pada pucuk merah iding-iding adalah alkaloid. Sebagai antipiretik, alkaloid dan steroid juga memiliki khasiat antiinflamasi (Adenan \& Suhartono, 2010). Antiinflamasi merupakan obat yang memiliki aktivitas menekan peradangan. Inflamasi disebabkan adanya rangsangan yang mencangkup luka fisik, infeksi, panas dan ineteraksi antigen antibodi (Katzung, 2002). Tingginya kandungan senyawa aktif pada pucuk merah iding-iding sangat baik untuk dijadikan antiinflamasi.

Proses ekstraksi menjadi kunci utama kefektifan dan efisien dalam pengembangan untuk memperoleh ekstrak aktif. Metode umumnya untuk ekstraksi adalah maserasi, sokletasi, perkolasi, dan refluks. Metode konvensional ini memiliki berbagai kelemahan diantaranya waktu ekstraksi yang lama, pelarut yang dibutuhkan banyak, serta jika dilakukan dalam suhu tinggi dapat merusak senyawa aktif itu sendiri. Salah satu pengembangan dari metode ekstraksi yaitu menggunakan PEF (Pulsed Electric Field). PEF adalah metode non termal yang menerapkan medan listrik tinggi dengan waktu yang singkat. Pada metode ini bahan diletakkan diantara dua elektroda. Listrik yang mengalir antara dua elektroda membantu meningkatkan permeabilitas membran sel (Lopez et al., 2008). Hal ini dikarenakan PEF (Pulsed Electric Field) menyebabkan pecahnya sel karena tegangan tinggi sehingga menaikkan konduktivitas elektrik dan permeabilitas membran sel dan metode ini akan menjadi solusi pada proses ekstraksi yang lama dan butuh pelarut yang banyak. Pada artikel ini membahas tentang ekstraksi senyawa-senyawa S. palustris Burm. yang berpotensi sebagai antiinflamasi menggunakan PEF.

\section{KANDUNGAN Stenochlaena palustris Burm. SEBAGAI AGEN ANTIINFLAMASI}

S. palustris Burm. mengandung senyawa alkaloid, flavonoid, antrakuinon, terpenoid, steroid, saponin, dan fenol hidrokuinon (Roasnica, 2018). S. palustris Burm. juga mengandung senyawa flavonoid kuersetin (4). Total flavonoid yang terkandung di dalam ekstrak S. palustris Burm. adalah 14,5 $\mathrm{gg} / \mathrm{ml}$. Ekstrak tanaman ini memiliki kandungan total flavonoid yang tinggi dibanding tanaman Gerunggang (Cratoxylum arborescens) dan Pasak Bumi (Eurycoma longifolia) yang merupakan tanaman obat di Kalimantan Selatan (Suhartono et al., 2012). Ekstrak pelepah daun S. palustris Burm. memiliki kandungan total polifenol tertinggi $(51,69 \mathrm{mg} / \mathrm{g}$ ekstrak kering), flavonoid $(58,05 \mathrm{mg} / \mathrm{g}$ ekstrak kering), dan asam hidroksisinamat (48,80 mg/g ekstrak kering) (Chau et al., 2012)<smiles>O=C(/C=C/c1ccc(O)cc1)OCCCC(O)C(O)COc1c(-c2ccc(O)cc2)oc2cc(O)cc(O)c2c1=O</smiles><smiles>O=c1c(O)c(-c2ccc(O)c(O)c2)oc2cc(O)cc(O)c12</smiles>

4

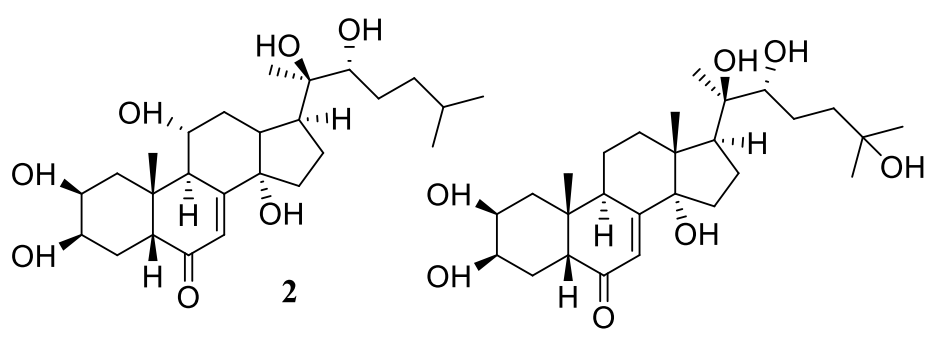

3<smiles>CCOC(=O)/C=C/c1ccc(OC)cc1</smiles>

5<smiles>NC(Cc1ccc(O)c(O)c1)C(=O)O</smiles>

6

Gambar 1. Kandungan senyawa pada S. palustris Burm: 1. Stenapalutrosida A; 2. Ajugasteron C; 3. 20hidroksiekdison; 4. Kuersetin; 5 . Etil-p-metoksi sinamat, 6 . Alkaloid turunan fenil alanin

Pardede et al. (2010) menemukan bahwa ekstrak daun S. palustris Burm mengandung senyawa stenapalutroside A (1), ajugasterone C (2), dan 20-hydroxyecdysone (3). Senyawa $\mathbf{2}$ dan $\mathbf{3}$ merupakan golongan senyawa steroid. Steroid sendiri telah banyak dilaporan memiliki aktivitas sebagai antiinflamasi (Pardede et al., 2018). Steroid menghambat aktivitas fosfolipase dan perubahan asam arakidonat menjadi prostaglandin, mengurangi kebocoran mikrovaskular, mencegah migrasi sel-sel piretik, dan menghambat produksi sitokin (Sudjarwo, 2005). Sedangkan senyawa 1 merupakan senyawa golongan flavonoid (flavonol) yang tersubstitusi glukosida dan asam sinamat. Flavonoid sendiri adalah kelompok senyawa polifenol yang 
memiliki aktivitas scavenger radikal bebas, penghambat enzim hydrolitic dan oksidatif, serta anti-inflamasi (Ntie-Kang et al., 2014) (Novika et al. 2021). Zat bioaktif lain pada S. palustris adalah alkaloid turunan fenil alanin (6). Alkaloid pada tumbuhan piperine juga terkandung di dalam S. palustris Burm. yang berfungsi sebagai antipiretik melalui penghambatan sintesis prostaglandin. kandungan senyawa yang telah dilaporkan terkandung dalam S. palustris Burm ditunjukkan pada Gambar 1.

Tabel 1. Senyawa dari Pucuk Merah Iding-iding dan aktivitasnya

\begin{tabular}{|c|c|c|c|}
\hline Senyawa & Tumbuhan & Aktivitas Biologis & Referesi \\
\hline \multirow[t]{5}{*}{ Flavonol } & Laurus nobilis & $\begin{array}{l}\text { Antiinflamasi, Antioksidan, } \\
\text { antibakteri }\end{array}$ & $\begin{array}{l}\text { (Alejo-Armijo et al., 2017) } \\
\text { (Mazura et al., 2007) }\end{array}$ \\
\hline & Melastoma malabathricum & $\begin{array}{l}\text { Antibakteri, Antioksidan, } \\
\text { Antiinflamasi }\end{array}$ & \\
\hline & Rosa canina $\mathrm{L}$ & $\begin{array}{l}\text { Antioksidan, } \\
\text { Antiinflamasi }\end{array}$ & (Nadpal et al., 2016) \\
\hline & $\begin{array}{l}\text { Scabiosa hymettia } \\
\text { S. stellata }\end{array}$ & Antimikroba, Antiinflamasi & $\begin{array}{l}\text { (Christopoulou et al., } \\
\text { 2008), (Mouffouk et al., } \\
\text { 2018) }\end{array}$ \\
\hline & Waltheria indica $\mathrm{L}$. & $\begin{array}{l}\text { Analgesik, Antiinflamasi, } \\
\text { Antikoksidan }\end{array}$ & $\begin{array}{l}\text { (Yougbare-Ziebrou et al., } \\
2016 \text { ) }\end{array}$ \\
\hline Ajugasterone C & Serratula coronata & Antioksidan, antimikroba & (Das et al., 2020) \\
\hline Ajugasterone A & V. doniana & Sitotoksik, antiinflamasi & (Das et al., 2020) \\
\hline \multirow[t]{3}{*}{ 20-hydroxyecdysone (3) } & V. doniana & Antiinflamasi & (Das et al., 2020) \\
\hline & Commelinaceae & Antiinflamasi & \\
\hline & Limnanthaceae & Antiinflamasi & \\
\hline Kuersetin & Buah-buahan & Antiinflamasi & (Comalada et al., 2005), \\
\hline
\end{tabular}

Beberapa senyawa tersebut (1-6) tedapat dalam beberapa ekstrak tumbuhan yang aktif sebagai antiinflamasi. Ajugasterone A, 20-hydroxyecdysone, kuersetin merupakan senyawa yang aktif sebagai antiinflamasi yang terdapat dari beberapa tumbuhan termasuk pucuk merah iding-iding. Namun senyawa 20-hydroxyecdysone dilaporkan paling banyak aktivitasnya sebagai antiinflamasi. Antiinflamasi merupakan obat yang memiliki aktivitas menekan peradangan. Inflamasi disebabkan adanya rangsangan yang mencangkup luka fisik, infeksi, panas dan ineteraksi antigen antibodi (Katzung, 2002). Berdasarkan kajian literatur didapatkan data berbagai macam ekstrak atau senyawa yang aktif sebagai antiinflamasi adalah seperti pada tabel di bawah ini :

Tabel 2. Perbandingan Aktivitas Antiinflamasi

\begin{tabular}{|c|c|c|c|}
\hline Kandungan Ekstrak & Aktivitas & Bagian & Referensi \\
\hline $\begin{array}{l}\text { Tanin } \\
\text { Flavonoid } \\
\text { Metil kavicol }\end{array}$ & $\begin{array}{c}\text { Menghambat radang yang diinduksi } \\
\text { keragenan } \\
\text { Dosis ekstrak } 50 \mathrm{mg} / \mathrm{kgBB}, 100 \mathrm{mg} / \mathrm{kgBB}, 250 \\
\mathrm{mg} / \mathrm{kgBB}\end{array}$ & $\begin{array}{l}\text { Daun Salam } \\
\text { (Eugenia } \\
\text { Polyantha) }\end{array}$ & Agustina, 2015 \\
\hline $\begin{array}{l}\text { Steroid, Flavonoid } \\
\text { Alkaloid } \\
\text { Tanin } \\
\text { Triterpenoid } \\
\text { Hidrokuinon } \\
\end{array}$ & $\begin{array}{l}\text { Menurunkan udem } \\
\text { dosis } 10 \% \\
\text { Dosis ekstrak } \\
5 \%, 10 \% \text { dan } 15 \%\end{array}$ & $\begin{array}{l}\text { Daun tanaman } \\
\text { Patah Tulang } \\
\text { (Euphorbia tirucalli } \\
\text { L.) }\end{array}$ & $\begin{array}{l}\text { Toana and Nasir, } \\
2010\end{array}$ \\
\hline $\begin{array}{l}\text { Saponin } \\
\text { Flavonoid } \\
\text { Alkaloid } \\
\text { Fenolik }\end{array}$ & $\begin{array}{l}\text { Menginhibisi edema kaki sebesar 69,42\% } \\
\text { Dosis ekstrak } \\
300 \mathrm{mg} / \mathrm{kg}\end{array}$ & Daun Buas-Buas & $\begin{array}{l}\text { Marbun et al., } \\
\qquad 2015\end{array}$ \\
\hline $\begin{array}{c}\text { Tanin } \\
\text { Flavonoid }\end{array}$ & $\begin{array}{c}\text { Menginhibisi edema kaki sebesar 37,77\% } \\
\text { Dosis ekstrak } 50 \text { mg/kg, } 100 \text { mg/kg, dan } 200\end{array}$ & Rimpang Kencur & $\begin{array}{l}\text { Hasanah et al., } \\
2011\end{array}$ \\
\hline
\end{tabular}


Jurnal Sains dan Edukasi Sains, Vol.4, No.2, Agustus 2021: 66-74

\begin{tabular}{|c|c|c|c|}
\hline Kandungan Ekstrak & Aktivitas & Bagian & Referensi \\
\hline $\begin{array}{l}\text { Polifenol } \\
\text { Kuinon } \\
\text { Triterpenoid }\end{array}$ & $\mathrm{m} / \mathrm{kg}$ & & \\
\hline $\begin{array}{l}\text { Steroid } \\
\text { Flavonoid }\end{array}$ & $\begin{array}{c}\text { Menurunkan volume edema kaki dengan } \\
\text { inhibisi sebesar } 89,55 \% \\
\text { Dosis ekstrak } 400 \mathrm{mg} / \mathrm{kg}\end{array}$ & $\begin{array}{c}\text { Daun Piladang } \\
\text { (Solenostemonscut } \\
\text { ell arioides (L) } \\
\text { Codd) }\end{array}$ & Aria et al, 2015 \\
\hline $\begin{array}{l}\text { Terpenoid } \\
\text { Flavonoid } \\
\text { Steroid }\end{array}$ & $\begin{array}{l}\text { Menginhibisi edema kaki sebesar 92,41\% } \\
\text { Dosis ekstrak } 300 \text { mg/kg }\end{array}$ & $\begin{array}{l}\text { Daun sawo manila } \\
\text { (Ciku Manilkara } \\
\text { zapota) }\end{array}$ & $\begin{array}{l}\text { Ganguly, } \\
2013\end{array}$ \\
\hline $\begin{array}{l}\text { Flavonoid } \\
\text { Alkaloid }\end{array}$ & $\begin{array}{c}\text { Menginhibisi edema kaki sebesar 67,2\% } \\
\text { Dosis ekstrak } 200 \mathrm{mg} / \mathrm{kg}\end{array}$ & $\begin{array}{l}\text { Daun geisel } \\
\text { (Mallotus } \\
\text { oppositifolius) }\end{array}$ & Nwaehujor, 2014 \\
\hline $\begin{array}{c}\text { Flavonoid } \\
\text { Fenol }\end{array}$ & $\begin{array}{c}\text { Menginhibisi edema kaki sebesar 90,91\% } \\
\text { Dosis ekstrak } 500 \mathrm{mg} / \mathrm{kg}\end{array}$ & $\begin{array}{c}\text { Daun cermai } \\
\text { (Phyllanthus acidus) }\end{array}$ & $\begin{array}{c}\text { Chakraborty, } \\
2012 \\
\end{array}$ \\
\hline Flavonoid & $\begin{array}{c}\text { Menginhibisi edema kaki sebesar 60,66\% } \\
\text { Dosis ekstrak } 300 \text { mg/KgBB }\end{array}$ & $\begin{array}{l}\text { Akar mangga } \\
\text { (Mangifera indica } \\
\text { Linn) }\end{array}$ & Latha, 2012 \\
\hline $\begin{array}{l}\text { Saponin } \\
\text { Isoflavonoid } \\
\text { Triterpenoid }\end{array}$ & $\begin{array}{c}\text { Menginhibisi edema kaki sebesar 38,23\% } \\
\text { Dosis ekstrak } 200 \mathrm{mg} / \mathrm{kg}\end{array}$ & $\begin{array}{l}\text { Daun urang aring } \\
\text { (Eclipta postrata L.) }\end{array}$ & $\begin{array}{l}\text { Arunachalam, } \\
2009\end{array}$ \\
\hline $\begin{array}{l}\text { Flavonoid } \\
\text { Tanin }\end{array}$ & $\begin{array}{c}\text { Menginhibisi edema kaki sebesar 62,9\% } \\
\text { Dosis ekstrak } 100 \mathrm{mg} / \mathrm{kg}, 200 \mathrm{mg} / \mathrm{kg} \text {, dan } 400 \\
\mathrm{mg} / \mathrm{kg}\end{array}$ & $\begin{array}{l}\text { Buah kenanga } \\
\text { (Conanga odorata } \\
\text { Lam.) }\end{array}$ & $\begin{array}{l}\text { Maniyar et al, } \\
2015\end{array}$ \\
\hline $\begin{array}{l}\text { Saponin } \\
\text { Flavonoid } \\
\text { Alkaloid } \\
\text { Fenol }\end{array}$ & $\begin{array}{c}\text { Mengurangi edema kaki sebesar 75,88\% } \\
\text { Dosis ekstrak } \\
400 \mathrm{mg} / \mathrm{kg}\end{array}$ & $\begin{array}{l}\text { Bunga Menara } \\
\text { (Leonotis } \\
\text { ocymifolia) }\end{array}$ & Alemu, 2018 \\
\hline
\end{tabular}

Adapun tumbuhan yang memiliki senyawa flavonoid dari tabel di atas adalah daun Salam, daun Patah Tulang, daun Buas-Buas, Rimpang Kencur, daun Piladang, daun Geisel, Sawo Manila, daun Cermai, akar Mangga, buah Kenanga, Bunga Menara dan Srikaya. Persentase terbaik untuk mengobati antiinflamasi yaitu Sawo Manila yang dapat menginhibisi edema kaki sebesar $92,41 \%$ pada ekstrak etil asetat dengan Dosis Ekstrak $300 \mathrm{mg} / \mathrm{kg}$. Kandungan yang terdapat pada daun sawo manila didominasi oleh terpenoid, steroid, dan flavonoid. Flavonoid yang terkandung di dalam daun sawo manila adalah mirsetin, apigenin, dan kuersetin (Fayek et al., 2012). Sedangkan kandungan terpenoid sawo manila berazil adalah $18 \%$ (Uekane et al., 2017). Kandungan ini menyerupai senyawa yang pada S. palustris Burm. sehingga tanaman ini sangat berpotensi sebagai antiinflamasi yang didukung oleh kajian etnobutani dari masyarakat Bangka Belitung yang percaya untuk digunakan sebagai obat nyeri dan bisul.

Senyawa lain yang bersifat sebagai antiinflamasi yang cukup kuat adalah golongan steroid. Senyawa steroid dari $V$. doniana seperti 20-hydroxyecdysone, Ajugasteron C, hydroxyshidasterone dan turunannya sangat aktif sebagai antiinflamasi (Das et al., 2020). Beberapa senyawa alkaloid tertentu telah dilaporkan memiliki senyawa aktivitas antiinflamasi seperti alkaloid brucin dari spons (Agrawal et al., 2011), epiisopiloturine dari pilocarpus microphyllus (Silva et al., 2013). Jika dibandingkan golongan flavonoid dan steroid, masih sedikit yang melaporkan senyawa alkaloid sebagai antiinflamasi.

\section{PEF (Pulsed Electric Field)}

Ekstraksi dapat dilakukan dengan beberapa metode diantaranya maserasi, perkolasi, digesti, refluks, sokletasi, maupun destilasi uap yang dapat dimodifikasi dengan pemanasan microwave, penggunaan ultrasonik, atau pemberian tegangan Pulse Electric Field (PEF). Ekstraksi sendiri menjadi kunci akan khasiat ekstrak dari tumbuhan. Beberapa metode membutuhkan panas sehingga dapat berakibat pada senyawa aktif yang diekstraksi yang mengalami degradari. Metode yang mudah dan aman sebenarnya ada metode maserasi, akan tetapi maserasi membutuhkan pelarut dan waktu yang lama. Terdapat pengembangan dalam metode ini dengan memadukan pemberian tegangan (PEF). PEF merupakan teknologi non-thermal yang menerapkan medan listrik tinggi dengan waktu yang singkat. 
Pada awalnya penggunaan tegangan tinggi pada bidang pangan untuk inaktivasi mikroba ataupun membunuh mikroba yang berkembang pada 1980an. Pengamatan menunjukkan adanya listrik tegangan tinggi sebesar $15 \mathrm{kV}$ dengan elektrode 1,6-6,4 mm dapat mensterilkan air dan sewage. Arus DC dengan tegangan tinggi dapat merusak membran sel pada bakteri. Kerusakan pada membran sel menyebabkan hilangnya sifat ireversibel membran yang berfungsi sebagai membran semipermeabel antara sel dan lingkungan, akibatnya akan menyebabkan kematian sel (Toepfl et al., 2007). Prinsip ini selanjutkan berkembang untuk ekstraksi. Prinsip kerja dari PEF yaitu memberikan kejutan listrik pada bahan dengan meletakkan sampel berupa biomaterial diantara dua elektroda pada pulse amplitude antara $0,1 \mathrm{kV} / \mathrm{cm}$ hingga $20 \mathrm{kV} / \mathrm{cm}$ dan didasarkan pada transformasi sel atau pecahnya sel karena tegangan yang dikenakan pada bahan yang dapat menaikkan konduktivitas elektrik dan permeabilitas membran sel. Berikut adalah ilustrasi kerja PEF :

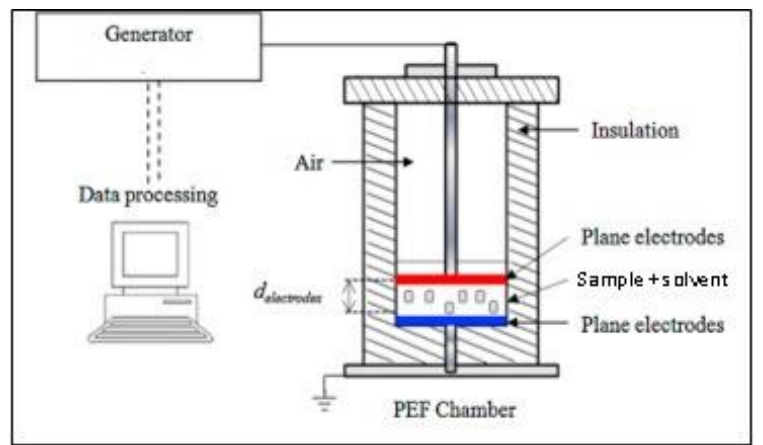

Gambar 2. Prinsip kerja dari metode PEF (Bouras et al., 2015)

Berdasarkan gambar di atas menunjukkan keefekifan dari metode PEF dalam mengekstraksi suatu senyawa, dikarenakan penggunaan medan listrik terhadap sel biomaterial menyebabkan perubahan struktur membran dan membuat ukuran pori sel membesar. Fenomena ini disebut electroporation atau electropermeabilisation yang mengakibatkan keluarnya kandungan intraseluler sel. Keunggulan dari metode ini adalah dapat mempertahankan warna, tekstur, dan aroma Original serta nilai nutrisi (Quass, 1997). Selain itu dibandingkan dengan metode lain seperti maserasi yang memiliki kelemahan waktu ekstraksi yang lama dan membutuhkan banyak pelarut, metode PEF ini dapat memperpendek waktu ekstraksi dan menurunkan kebutuhan pelarut.

Penggunaan PEF dapat meningkatkan jumlah polifenol dalam tomat (Solanum lycopersicum) dan anggur (Vitis vinifera). Pada penelitian sebelumnya dalam ekstraksi daun Torbangun (Coleus amboinicus), telah dilakukan pretreatment menggunakan PEF dengan kuat medan listrik sebesar 3,5 kV/cm selama 20 detik (Dewi et al., 2019). Selain itu, dalam penelitian ekstraksi tanin biji pinang juga dilakukan tahapan PEF dengan kuat medan listrik $5 \mathrm{kV} / \mathrm{cm} 1$ detik hingga 2 jam (Rahmah et al., 2019). Penggunaan PEF dengan rasio bahan: pelarut 1:8 selama 6 detik menghasilkan total fenolik $5.87 \mathrm{mg} \mathrm{GAE} / \mathrm{g}$ dengan rendemen 70.74\%. Goettel et al. (2013) menyatakan pengaruh energi perlakuan spesifik pada PEF dengan suspensi 52-211 kJ / kg, kekuatan medan listrik 23-43 kV / cm, dan konsentrasi biomassa 36-167 g berat kering per kg suspensi pada disintegrasi sel menyebabkan pelepasan zat intraseluler larut ke dalam suspensi sehingga efisiensi disintegrasi meningkat. Puértolas et al. (2012) menyatakan penggunaan metode PEF $3,4 \mathrm{kV} / \mathrm{cm}$ dan 105 detik (35 / 3 detik) menghasilkan indeks disintegrasi sel tertinggi $(Z p=1)$ pada kebutuhan energi spesifik terendah $(8,92 \mathrm{~kJ} / \mathrm{kg})$ sehingga hasil yang diperoleh menjadi lebih tinggi pada suhu ekstraksi yang lebih rendah dengan air sebagai pelarut. Setelah 480 menit pada $40 \mathrm{C}$, untuk sampel yang tidak diolah menggunakan etanol $96 \%$ sebagai pelarut $(63,9 \mathrm{mg} / 100 \mathrm{~g})$ mirip dengan yang diperoleh dalam sampel yang diolah PEF menggunakan air $(65,8 \mathrm{mg} / 100 \mathrm{~g})$. Oleh karena itu, PEF dimungkinkan dengan air, pelarut yang lebih ramah lingkungan daripada etanol. Prospek teknologi PEF dalam indsutri herbal yaitu kekuatan medan listrik ini baru memungkinkan pada skala laboratorium atau pilot plant, sedangkan untuk unit skala komersial masih memerlukan voltase yang lebih tinggi atau pengaturan elektroda khusus untuk mencapai kondisi yang dikehendaki dalam mengekstraksi tanaman dalam jumlah besar (Troy et al., 2016).

\section{KESIMPULAN}

Pucuk merah iding-iding (Stenochlaena Palustris) merupakan salah satu jenis tumbuhan pakupakuan, yang banyak juga dikenal dengan nama lemidi, lemiding, ramiding, pau raurau, paku hurang, dan kelakai. Kandungan dari pucuk merah iding-iding sendiri telah dilaporkan mengandung senyawa Stenapalutrosida A, kersetin, dan 20-hydroxyecdysone. Senyawa tersebut telah banyak dilaporkan memiliki 
aktivitas antiinflamasi. Prospek untuk ekstraksi senyawa aktif tersebut dapat menggunakan metode PEF. Metode PEF (Pulsed Electric Field) merupakan metode terbarukan yang efektif dalam mengekstrak senyawa aktif tanaman seperti Pucuk merah iding-iding (Stenochlaena Palustris). PEF merupakan teknologi nonthermal yang menerapkan medan listrik tinggi dengan waktu yang singkat. Sehingga teknologi ini mempunyai prospek untuk ekstraksi dalam industri herbal.

\section{UCAPAN TERIMAKASIH}

Penelitian ini didanai oleh Kementerian Pendidikan dan Kebudayaan - Direktorat Jenderal Pendidikan Tinggi melalui skema PKM-PE 2020

\section{DAFTAR PUSTAKA}

Adenan \& Suhartono E. (2010). Sten-ochlaena palustris aqueous extract reduc-eshepatic peroxidative stress in Marmota cdlligata with induce fever. Universa Medicina, 29, 3.

Agrawal, S. S., Saraswati, S., Mathur, R., \& Pandey, M. (2011). Brucine, a plant derived alkaloid inhibits inflammatory angiogenesis in a murine sponge model. Biomedicine and Preventive Nutrition, 1(3), 180-185. https://doi.org/10.1016/j.bionut.2011.06.014

Agustina R., Indrawati D.T., \& Masruhin, M.A. (2015). Aktivitas Ekstrak Daun Salam (Eugenia Polyantha) Sebagai Antiinflamasi Pada Tikus Putih (Rattus Norvegicus). J. Trop. Pharm. Chem, 3(2). 120-123

Alejo-Armijo, A., Altarejos, J., \& Salido, S. (2017). Phytochemicals and biological activities of laurel tree (Laurus nobilis). Natural Product Communications, 12(5), 743-757. https://doi.org/10.1177/1934578×1701200519

Alemu, A., Tamiru, W., Nedi, T., \& Shibeshi, W. (2018). Analgesic and Anti-Inflammatory Effects of $80 \%$ Methanol Extract of Leonotis ocymifolia (Burm.f.) Iwarsson Leaves in Rodent Models. EvidenceBased Complementary and Alternative Medicine. 2018, 1-8.

Aria, M., Verawati, A, Afdhil, A., \& Monika. (2015). Uji Efek Antiinflamasi Fraksi Daun Piladang (Solenostemons cutellarioides (L.) Codd) terhadap Mencit Putih Betina. Scientia, 5(2).

Ariyantini, M. D, Fauzi, M., \& Jayus. (2017). Inaktivasi Enzim Protease Pada Puree Edamame (Glycine max) Menggunakan Teknik Pulsed Electric Field (PEF). Jurnal Agroteknologi, 11 (2). 164-171.

Arunachalam, G., Subramanian, N., Pazhani, G, P., \& Ravichandran V. (2009). Anti inflammatory activity of methanolic extract of Eclipta prostrate L. (Astearaceae). African journal of pharmacy and Pharmacology, 3(3), 097-100

Bouras, M., Chadni, M., Barba, F. J., Grimi, N., Bals, O., Vorobiev, E. (2015). Optimization of microwaveassisted extraction of polyphenols from Quercus bark, Industrial Crops and Products, 77, 590-601

Chai, T.T., Panichellvum, E., Ong, H.C., Wong, F.C., (2012). Phenolic Contents and Antioxidant Properties of Stenichlanaena palustris, and Edible Medicinal Fem. Botanical studies, 53. 439-4

Christopoulou, C., Graikou, K., \& Chinou, I. (2008). Chemosystematic value of chemical constituents from Scabiosa hymettia (Dipsacaceae). Chemistry and Biodiversity, 5(2), 318-323. https://doi.org/10.1002/cbdv.200890029

Comalada, M., Camuesco, D., Sierra, S., Ballester, I., Xaus, J., Gálvez, J., \& Zarzuelo, A. (2005). In vivo quercitrin anti-inflammatory effect involves release of quercetin, which inhibits inflammation through down-regulation of the NF-KB pathway. European Journal of Immunology, 35(2), 584-592. https://doi.org/10.1002/eji.200425778

Das, N., Mishra, S. K., Bishayee, A., Ali, E. S., \& Bishayee, A. (2020). The phytochemical, biological, and medicinal attributes of phytoecdysteroids: an updated review. Acta Pharmaceutica Sinica $B, x x x$. 
https://doi.org/10.1016/j.apsb.2020.10.012

Dewi, S.R., Sumarni, N., Izza, N., Putranto, A.W., \& Susilo, B. (2019). Studi Variasi Kuat Medan Listrik PEF dan Metode Pengeringan Bahan terhadap Senyawa Antioksidan Ekstrak Daun Torbangun (Coleus amboinicus L.), Jurnal Keteknikan Pertanian, 7(1), 91-97

Fayek, N.M., Monem, A.R., Mossa, M.Y., Meselhy, M.R., \& Shazly., A.H. (2012). Chemical and biological study of Manilkara zapota (L.) van Royen leaves (Sapotaceae) cultivated in Egypt. Pharmacognosy Res. 4, 85-91. doi: 10.4103/0974-8490.94723.

Ganguly A., Al Mahmud, Z., Uddin, M. M. N., \& Rahman, S. A. (2013). In-vivo anti-inflammatory and antipyretic activities of Manilkara zapota leaves in albino Wistar rats. Asian Pacific Journal of Tropical Disease, 3(4). 301-307.

Hasanah, A.N., Nazaruddin, F., Febrina, E., \& Zuhrotun, A., (2011). Analisis Kandungan Minyak Atsiri dan Uji Aktivitas Antiinflamasi Ekstrak Rimpang Kencur (Kaempferia galanga L.). Jurnal Matematika \& Sains 16 (3), 149-151

Katzung, B.G., Master, S.B., \& Trevelor, A.J (2006). Basic and Cinical Pharmacology, 10th Edition. The McGraw-Hill Companies. USA

Latha, M.S., Latha K.P., Vagdevi, H.M., \& Virupaxappa, S.B. (2012). Anti-inflammatory activity of Mangifera indica L. Var Rasapuri root extracts. J Chem Pharm. 4, 333-336.

Lopez, N., Puertolas, E., Condon, S., Alvarez, I., \& Raso, J. (2008). Application Of Pulsed Electric Fields For Improving The Maceration Process During Vinification Of Red Wine: Influence Of Grape Variety. Eur Food Res Technol, 227, 1099-1107

Goettel, M., Eing, C., Gusbeth, C., Straessner, R., \& Frey, W. (2013). Pulsed electric field assisted extraction of intracellular valuables from microalgae. Algal Research, 2(4), 401-408.

Maniyar, Yasmin, H., \& Devi, J. (2015). Evaluation of anti-infl ammatory activity of ethanolic extract of Cananga odorata Lam in experimental animals. Int J Basic Clin Pharmacol. 4(2), 354-357

Marbun, E.M.A., \& Restuati, M., (2015). Pengaruh Ekstrak Etanol Daun Buas-Buas (Premna pubescens Blume) Sebagai Antiinflamasi Pada Edema Kaki Tikus Putih (Rattus novergicus). Jurnal Biosains 1(3), 108.

Mazura, M. P., Susanti, D., \& Rasadah, M. A. (2007). Anti-inflammatory action of components from Melastoma malabathricum. Pharmaceutical Biology, 45(5), 372-375. https://doi.org/10.1080/13880200701214797

Mouffouk, C., Hambaba, L., Haba, H., Mouffouk, S., Bensouici, C., Mouffouk, S., Hachemi, M., \& Khadraoui, H. (2018). Acute toxicity and in vivo anti-inflammatory effects and in vitro antioxidant and antiarthritic potential of Scabiosa stellata. Oriental Pharmacy and Experimental Medicine, 18(4), 335348. https://doi.org/10.1007/s13596-018-0320-3

Nadpal, J. D., Lesjak, M. M., Šibul, F. S., Anačkov, G. T., Četojević-Simin, D. D., Mimica-Dukić, N. M., \& Beara, I. N. (2016). Comparative study of biological activities and phytochemical composition of two rose hips and their preserves: Rosa canina L. and Rosa arvensis Huds. Food Chemistry, 192, 907-914. https://doi.org/10.1016/j.foodchem.2015.07.089

Ntie-Kang, F., Onguéné, P.O., Lifongo, L.L., Ndom, J.C., Sippl, W., \& Mbaze, L.M. (2014). The Potential of Anti-malarial Compounds Derived From African Medicinal Plants, Part II : a Pharmalogical Evaluation of Non- Alkaloids and Non-Terpenoids. Malaria Journal, 13:81. doi: 10.1186/1475-287513-81. 
Novika, D., Ahsanunnisa, R., \& Yani, D. (2021). Uji Aktivitas Antiinflamasi Ekstrak Etanol Daun Belimbing Wuluh (Averrhoa bilimbi L.) Terhadap Penghambatan Denaturasi Protein. Stannum : Jurnal Sains Dan Terapan Kimia, 3(1), 16-22. https://doi.org/10.33019/jstk.v3i1.2117

Nurjanah, Izzati, L., \& Abdullah, A. (2011). Aktivitas antioksidan dan komponen bioaktif kerang pisau (Solen spp.). Jurnal Ilmu Kelautan, 16(3), 119-124.

Nwaehujor, C.O., Ezeja, M.I., Udeh, N.E, Okoye, D.N., \& Udegbunam, R.I. (2014). Anti-inflammatory and anti-oxidant activities of Mallotus oppositifolius (Geisel) methanol leaf extracts. Arabian Journal of Chemistry 7(1); 805-810.

Pardede, A., Adfa, M., Kusnanda, A. J., Ninomiya, M., \& Koketsu, M. (2018). Isolation of secondary metabolites from Stenochlaena palustris stems and structure-activity relationships of 20hydroxyecdysone derivatives on antitermite activity. Holzforschung, 72(10), 899-904.

Puértolas, E., Cregenzán, O., Luengolgnacio, L., \& Raso, A.J. (2012). Pulsed-electric-field-assisted extraction of anthocyanins from purple-fleshed potato. Food Chemistry, 136, 1330-1336

Quass, D. W. 1997. Pulsed Electric Field Processing In The Food Industry. A Status Report On Pulsed Electric Field. Palo Alto, CA. Electric Power Research Institute. Page 23-35. CR- 109742.

Rahmah, N.L., Sukardi, \& Dila, I.N. (2019). Aplikasi Perlakuan Pendahuluan Pulsed Electric Field (PEF) pada Ekstraksi Tanin Biji Pinang (Areca catechu) (Kajian Frekuensi dan Waktu PEF). Jurnal Teknologi Industri Pertanian, 29 (1) : 46.

Roanisca, O. (2018). Skrining Fitokimia Dan Potensi Antibakteri Ekstrak Etanol Pucuk Iding-Iding ( Stenochlaena palustris ) Terhadap Bakteri Bacillus subtilis, Staphylococcus aureus, dan Escherichia coli Phytochemical Screening And Antibacterial Potency Of Ethanolic Extract. Jurnal Kimia Mulawarman, 15(2012), 99-105.

Roanisca, O., \& Mahardika, R.G. (2017). Screaning Fitokimia dan Aktivitas Antioksidan dari Ekstrak Aseton Pucuk Iding-Iding (Stenochlaena palustris) Bangka. Prosiding SNPPM FT UBB.

Silva, V. G., Silva, R. O., Damasceno, S. R. B., Carvalho, N. S., Prudeîncio, R. S., Aragão, K. S., Guimarães, M. A., Campos, S. A., Véras, L. M. C., Godejohann, M., Leite, J. R. S. A., Barbosa, A. L. R., \& Medeiros, J. V. R. (2013). Anti-inflammatory and antinociceptive activity of epiisopiloturine, an imidazole alkaloid isolated from pilocarpus microphyllus. Journal of Natural Products, 76(6), 1071-1077. https://doi.org/10.1021/np400099m

Sudjarwo S. A. (2005). The Potency of Piperine as Antiinflamatory and Analgesic in Rats and Mice. Folia Medica Indonesiana, 41, 3

Suhartono, E. (2012). Total Flavonoid and Antioxidant Activity of Some Selected Medicinal Plants in South Kalimantan of Indonesian. APCBEE Procedia 4, 235-239.

Toana, M. H. \& Nasir, B. (2010). Studi Bioaktif dan Isolasi Senyawa Bioaktif Tumbuhan Euphorbia tirucalli (Euphorbiaceae) sebagai Insektisida Botani Alternatif. Journal Agroland. 17(1): 47-55.

Toepfl, S., Heinz, V., Institut, D., Dil, V., \& Knorr, D. (2007). History of pulsed electric field treatment. In Food preservation by pulsed electric fields: From research to application (Issue Dil). Woodhead Publishing Limited. https://doi.org/10.1533/9781845693831.9

Troy, D.J., Ojha, K. S. , Kerry, J. P. \& Tiwari, B. K. (2016.) Sustainable and consumer-friendly emerging technologies for application within the meat industry: An overview. Meat Science 120:2-9.

Uekane, T. M., Nicolotti, L., Griglione, A., Bizzo, H. R., Rubiolo, P., Bicchi, C., Rocha-Leão, M. H. M., \& Rezende, C. M. (2017). Studies on the volatile fraction composition of three native Amazonian- 
Brazilian fruits: Murici (Byrsonima crassifolia L., Malpighiaceae), bacuri (Platonia insignis M., Clusiaceae), and sapodilla (Manilkara sapota L., Sapotaceae). Food Chemistry, 219, 13-22. https://doi.org/10.1016/j.foodchem.2016.09.098

WHO. 2018, June 1. World Healt Organization. Diambil kembali dari Noncommunicable desease: https://www.who.int/news-room/fact-sheets/detail/noncommunicable-diseases.

Yougbare-Ziebrou, M. N., Lompo, M., Ouedraogo, N., Yaro, B., \& Guissoun, I. P. (2016). Antioxidant, analgesic and anti-inflammatory activities of the leafy stems of Waltheria indica L. (Sterculiaceae). Journal of Applied Pharmaceutical Science, 6(2), 124-129. https://doi.org/10.7324/JAPS. 